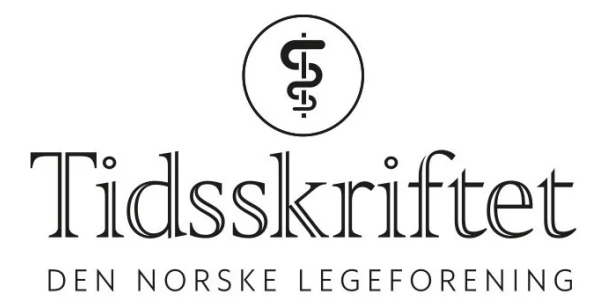

\title{
Høyere dose hydroksyurea ved sigdcellesykdom
}

FRA ANDRE TIDSSKRIFTER

KRISTOFFER BRODWALL

kristoffer.brodwall@gmail.com

Haukeland universitetssjukehus

Legemiddelet hydroksyurea er trygt og effektivt for barn med sigdcellesykdom, men mange bør få høyere dose enn det praksis har vært hittil.

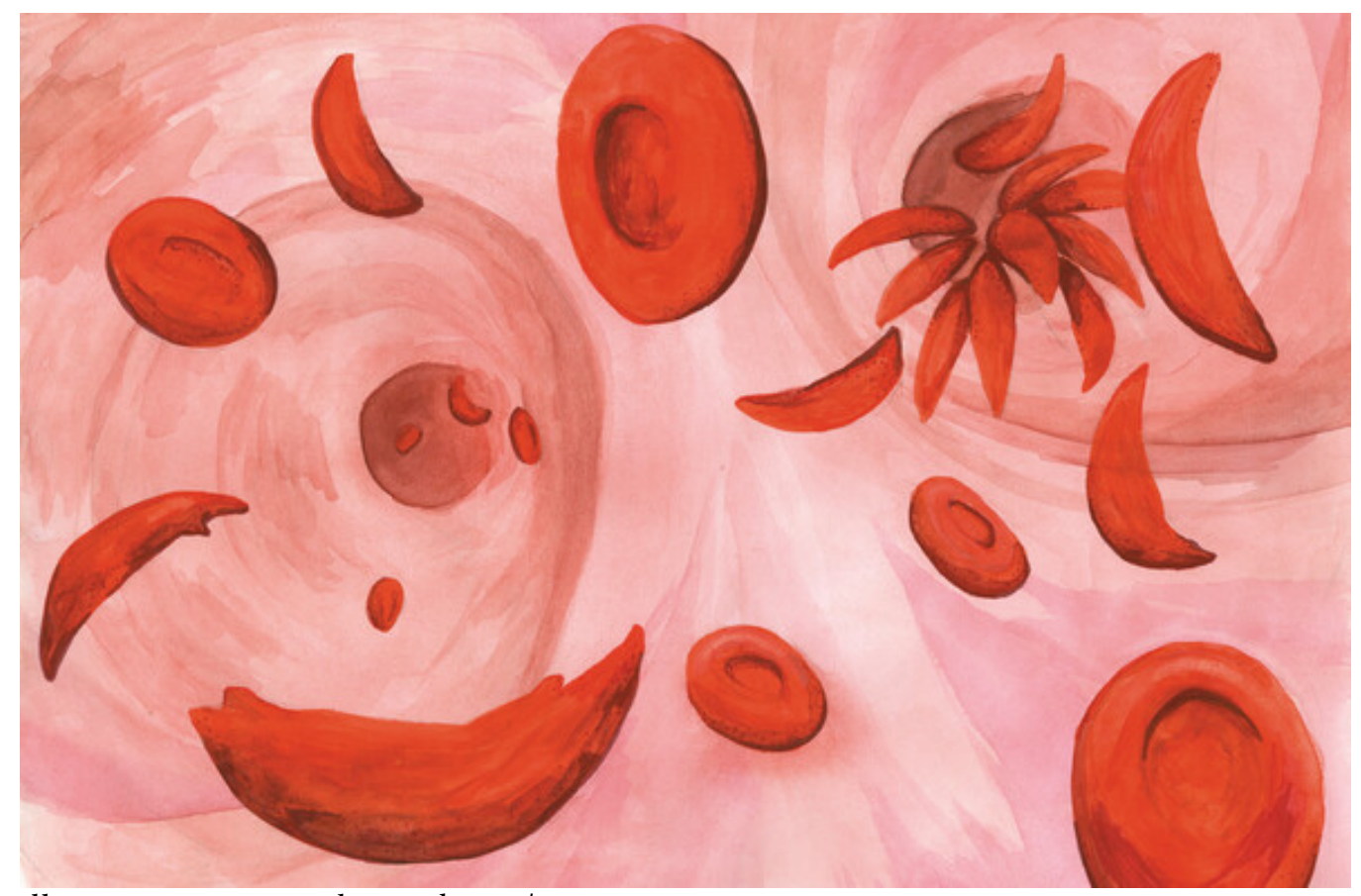

Illustrasjon: Science Photo Library / NTB scanpix

Ved sigdcellesykdom får erytrocyttene en kantete, halvmånelignende form. De sprekker lett, hvilket gir hemolytisk anemi, og de klumper seg lett sammen, hvilket gir vasookklusjon og dermed organskade. 
Mutasjonen som gir sykdommen, sitter i genet for adult hemoglobin (HbA), mens det føtale hemoglobinet (HbF) er normalt. Behandling med hydroksyurea (også kjent som hydroksykarbamid) stimulerer til dannelse av mer føtalt hemoglobin, og reduserer derfor symptomer og komplikasjoner ved sigdcellesykdom.

Barn med sigdcellesykdom skal behandles med hydroksyurea, men optimal dosering er ikke fastlagt. I en ny studie fra Uganda ble behandling med standard dose, dvs. 20 mg per kg kroppsvekt, sammenliknet med gradvis doseøkning opp mot $35 \mathrm{mg} / \mathrm{kg}$, under monitorering av mulige bivirkninger, spesielt måling av leukocytter og trombocytter (1). Studien omfattet 187 barn i 4-5-årsalderen. Alle ble behandlet med standard dose hydroksyurea ved inngangen til studien, men ble så randomisert til enten å gradvis øke dosen eller å fortsette med samme dose.

Studien var planlagt for to år, men ble stoppet etter 18 måneder pga. en klart gunstig effekt av høyere dose. Om lag 86 \% av barna i intervensjonsgruppen hadde da oppnådd studiens primære endepunkter, dvs. $\mathrm{Hb}>$ 9,o g/dl eller mer enn 20 \% føtalt hemoglobin (versus $37 \% \mathrm{i}$ kontrollgruppen). Intervensjonsgruppen hadde dessuten færre episoder med symptomer fra sigdcellesykdommen, f.eks. hadde de sjeldnere smerter fra vasookklusive kriser, sjeldnere acute chest syndrome, sjeldnere lungebetennelse og sjeldnere behov for blodoverføring. De ble også sjeldnere innlagt på sykehus.

Forskerne bak studien konkluderer med at barn med sigdcellesykdom i Afrika sør for Sahara kan ha nytte av høyere dose hydroksyurea, men at doseøkningen må individualiseres fordi noen barn får bivirkninger grunnet beinmargspåvirkning.

\section{LITTERATUR}

1. John CC, Opoka RO, Latham TS et al. Hydroxyurea dose escalation for sickle cell anemia in subsaharan Africa. N Engl J Med 2020;382: 2524-33. [PubMed][CrossRef]

Publisert: 12. oktober 2020. Tidsskr Nor Legeforen. DOI: 10.4045/tidsskr.20.0661

(C) Tidsskrift for Den norske legeforening 2023. Lastet ned fra tidsskriftet.no 26. april 2023. 